\title{
Pelayanan Tenaga Administrasi Sekolah Urusan Kurikulum Berbasis Teknologi Informasi di SMK se-Kota Padang Panjang
}

\author{
Ines Chairunnisa ${ }^{1}$, Rusdinal ${ }^{2}$, Ermita ${ }^{3}$, Hanif Al Kadri ${ }^{4}$ \\ 1,2,3,4 Administrasi Pendidikan, Universitas Negeri Padang \\ Ines Chairunnisa ${ }^{1}$, e-mail: ineschai98@gmail.com \\ Rusdinal ${ }^{2}$, email: rusdinal@ fip.unp.ac.id \\ Ermita $^{3}$, email: ermitarustam1114@gmail.com \\ Hanif Al Kadri ${ }^{4}$, email: hanifalkadri@fip.unp.ac.id
}

\begin{abstract}
This study aims to obtain information about the services of school administration staff in information technology-based curriculum affairs seen from the following aspects: 1) information availability, 2) responsiveness and 3) ease of use. This research is descriptive quantitative in nature with the population in this study are teachers of all SMK-Kota Padang Panjang, amounting to 149 teachers and a sample of 62 teachers. The instrument used was a questionnaire in the form of a Likert scale that was valid and reliable. The research shows the availability of information from the service of school administration personnel for information technology-based curriculum affairs reaches a score of 3.83 in the good category, the responsiveness aspect reaches a score of 4.04 in the good category and the aspect of ease of use reaches a score of 4.02 in the good category. Based on these results, the overall service of school administration staff for information technology-based curriculum affairs in Vocational High Schools in Padang Panjang has gone well with a score of 3.96 .
\end{abstract}

\begin{abstract}
Abstrak
Penelitian ini bertujuan untuk mendapatkan informasi tentang pelayanan tenaga administrasi sekolah urusan kurikulum berbasis teknologi informasi yang dilihat dari aspek: 1) ketersediaan informasi, 2) ketanggapan dan 3) kemudahan penggunaan. Penelitian ini bersifat deskriptif kuantitatif dengan populasi dalam penelitian ini adalah guru se SMK-Kota Padang Panjang yang berjumlah 149 orang guru dan sampel sebanyak 62 orang guru. Instrumen yang digunakan berupa kuesioner dalam bentuk skala likert yang telah valid dan reliabel. Penelitian menunjukkan ketersediaan informasi dari pelayanan tenaga administrasi sekolah urusan kurikulum berbasis teknologi informasi mencapai skor 3,83 dalam kategori baik, aspek ketanggapan mencapai skor 4,04 dengan kategori baik dan aspek kemudahan penggunaan mencapai skor 4,02 dalam kategori baik. Berdasarkan hasil tersebut secara keseluruhan pelayanan tenaga administrasi sekolah urusan kurikulum berbasis teknologi informasi di SMK se-Kota Padang Panjang sudah berjalan baik dengan ketercapaian skor 3,96.
\end{abstract}

Kata Kunci: Pelayanan, TAS, Teknologi Informasi

How to Cite: Chairunnisa, Ines 1, Rusdinal 2. 2021. Pelayanan Tenaga Administrasi Sekolah Urusan Kurikulum Berbasis Teknologi Informasi di SMK se-Kota Padang Panjang. Journal Educational Administration and Leadership, Vol (N): pp. XX-XX, DOI: 10.24036/XXXXXXXXXX-X-XX

This is an open access article distributed under the Creative Commons 4.0 Attribution License, which permits unrestricted use, distribution, and reproduction in any medium, provided the original work is properly cited. (C2020 by author.

\section{Pendahuluan}

Semakin majunya perkembangan zaman yang syarat dengan pemanfaatan teknologi informasi saat ini turut mempengaruhi segala kehidupan manusia. Dunia semakin bergeser menuju era digital sehingga teknologi informasi telah menjadi bagian dari kebutuhan setiap orang. Salah satu sektor yang memanfaatkan kecanggihan teknologi informasi adalah sektor pendidikan. Sekolah sebagai lembaga pendidikan merupakan lembaga yang berperan penting dalam menghasilkan sumber daya manusia yang memiliki kualifikasi dan kompetensi yang tinggi. Sekolah harus dikelola secara efektif dan efisien untuk dapat mencapai tujuan tersebut. Salah satu sumber daya manusia yang terlibat di sekolah adalah tenaga kependidikan yang salah satunya adalah tenaga administrasi sekolah. Tenaga administrasi sekolah merupakan tenaga kependidikan yang memegang peranan 
Ines Chairunnisa ${ }^{1}$, Rusdinal ${ }^{2}$, Ermita $^{3}$, Hanif Al Kadri ${ }^{4}$

Pelayanan Tenaga Administrasi Sekolah Urusan Kurikulum Berbasis Teknologi Informasi di SMK se-Kota Padang Panjang

penting dalam meningkatkan pelayanan administrasi sekolah. Menurut (Zulkarnain dan Raden, 2015) tenaga administrasi sekolah adalah tenaga kependidikan yang bertugas memberikan layanan administrasi guna terselenggaranya proses pendidikan di sekolah. Pengelolaan administrasi sekolah yang baik sangat dibutuhkan dalam memberikan pelayanan administrasi sekolah karena tidak dapat dipungkiri bahwa setiap manusia membutuhkan pelayanan yang efektif dan efisien agar dapat meningkatkan pengetahuannya terhadap informasi yang dibutuhkan. Dengan memanfaatkan teknologi informasi dalam memberikan pelayanan administrasi sekolah akan membantu mengoptimalisasi kualitas dari pelayanan. Berdasarkan Permendiknas No.24 tahun 2008 tentang standar tenaga administrasi sekolah/madrasah, salah satu tenaga administrasi sekolah adalah urusan kurikulum. Kurikulum merupakan faktor yang turut mempengaruhi keberhasilan program pendidikan, untuk itu diperlukan pelayanan yang berkualitas dalam urusan kurikulum agar dapat meningkatkan kualitas output yang dihasilkan yaitu dengan menggunakan teknologi informasi. Menurut (Tjiptono, 2012) salah satu cara efektif untuk mewujudkannya adalah dengan memanfaatkan teknologi informasi sebagai sarana dalam melakukan pelayanan.

Namun yang terjadi di lapangan berdasarkan pengamatan dan wawancara yang dilakukan kepada beberapa guru ditemukan 1) masih adanya tenaga administrasi sekolah urusan kurikulum yang mengalami kesulitan dan kebingungan dalam menggunakan teknologi informasi, 2) masih adanya tenaga administrasi sekolah urusan kurikulum yang sering meminta bantuan dalam menggunakan teknologi informasi, 3) masih adanya tenaga administrasi sekolah urusan kurikulum yang menggunakan cara manual pada beberapa tugasnya, 4) masih adanya tenaga administrasi sekolah urusan kurikulum yang belum menggunakan penyimpanan data online.

Berdasarkan beberapa uraian di atas penelitian ini berguna untuk mendapatkan informasi tentang seberapa baik pelayanan tenaga administrasi sekolah urusan kurikulum berbasis teknologi informasi di SMK se-Kota Padang Panjang yang dilihat dari aspek ketersediaan informasi, ketanggapan dan kemudahan penggunaan.

\section{Metode Penelitian}

Penelitian ini berjenis deskriptif kuantitatif dengan populasi seluruh guru di SMK se-Kota Padang Panjang yang berjumlah 149 orang. Jumlah sampel sebanyak 62 orang dengan teknik penarikan sampel simple random sampling. Instrumen pengumpulan data dalam penelitian ini berupa kuesioner dengan model skala likert. Menurut (Sugiyono, 2018) skala likert digunakan untuk mengukur sikap, pendapat dan persepsi seseorang atau sekelompok orang terhadap suatu fenomena sosial.

\section{Hasil dan Pembahasan}

\subsection{Hasil Penelitian}

Data hasil penelitian mengenai pelayanan tenaga administrasi sekolah urusan kurikulum berbasis teknologi informasi dapat dilihat dari masing-masing indikator yaitu:

1. Ketersediaan informasi

Hasil pengolahan data mengenai ketersediaan informasi dalam pelayanan tenaga administrasi sekolah urusan kurikulum berbasis teknologi informasi dapat dilihat dari 4 sub indikator yaitu kepadatan informasi, relevan, akurat, dan kejelasan informasi.

Tabel 1. Deskripsi data ketersediaan informasi dalam pelayanan tenaga administrasi sekolah urusan kurikulum berbasis teknologi informasi

\begin{tabular}{|c|l|c|c|}
\hline No. & \multicolumn{1}{|c|}{$\begin{array}{c}\text { Sub Indikator Ketersediaan } \\
\text { informasi }\end{array}$} & Jumlah Skor Rata-rata & Kategori \\
\hline 1 & Kepadatan informasi & 4,02 & Baik \\
\hline 2 & Relevan & 3,90 & Baik \\
\hline 3 & Akurat & 3,67 & Baik \\
\hline 4 & Kejelasan & 3,73 & Baik \\
\hline \multicolumn{2}{|c|}{ Rata-rata } & 3,83 & Baik \\
\hline
\end{tabular}

Berdasarkan tabel 1 secara keseluruhan terlihat bahwa ketersediaan informasi dalam pelayanan tenaga administrasi sekolah urusan kurikulum berbasis teknologi informasi mencapai skor 3, 83 dengan kategori baik.

2. Ketanggapan

Hasil pengolahan data mengenai ketanggapan dalam pelayanan tenaga administrasi sekolah urusan kurikulum berbasis teknologi informasi dapat dilihat dari 2 sub indikator yaitu cepat dan tepat Tabel 2. Deskripsi data ketanggapan dalam pelayanan tenaga administrasi sekolah urusan kurikulum berbasis teknologi informasi

\begin{tabular}{|c|l|c|c|}
\hline No. & Sub Indikator Ketanggapan & Jumlah Skor Rata-rata & Kategori \\
\hline 1 & Cepat & 4,03 & Baik \\
\hline 2 & Tepat & 4,04 & Baik \\
\hline
\end{tabular}


Ines Chairunnisa ${ }^{1}$, Rusdinal ${ }^{2}$, Ermita $^{3}$, Hanif Al Kadri ${ }^{4}$ Pelayanan Tenaga Administrasi Sekolah Urusan Kurikulum Berbasis Teknologi Informasi di SMK se-Kota Padang Panjang

\begin{tabular}{|c|c|c|}
\hline Rata-rata & 4,04 & Baik \\
\hline
\end{tabular}

Berdasarkan tabel 2 secara keseluruhan terlihat bahwa ketanggapan dalam pelayanan tenaga administrasi sekolah urusan kurikulum berbasis teknologi informasi mencapai skor 4,04 dengan kategori baik

3. Kemudahan Penggunaan

Hasil pengolahan data mengenai kemudahan penggunaan dalam pelayanan tenaga administrasi sekolah urusan kurikulum berbasis teknologi informasi dapat dilihat dari 5 sub indikator yaitu mudah dipelajari, mudah dioperasikan, mudah mengerjakan yang diinginkan, tidak butuh banyak usaha, dan fleksibel.

Tabel 3. Deskripsi data kemudahan penggunaan dalam pelayanan tenaga administrasi sekolah urusan kurikulum berbasis teknologi informasi

\begin{tabular}{|c|l|c|c|}
\hline No. & \multicolumn{1}{|c|}{$\begin{array}{c}\text { Sub Indikator Kemudahan } \\
\text { Penggunaan }\end{array}$} & Jumlah Skor Rata-rata & Kategori \\
\hline 1 & Mudah dipelajari & 4,06 & Baik \\
\hline 2 & Mudah dioperasikan & 4,08 & Baik \\
\hline 3 & $\begin{array}{l}\text { Mudah mengerjakan yang } \\
\text { diinginkan }\end{array}$ & 3,98 & Baik \\
\hline 4 & Tidak butuh banyak usaha & 3,96 & Baik \\
\hline 5 & Fleksibel & 4,02 & Baik \\
\hline & Rata-rata & 4,02 & Baik \\
\hline
\end{tabular}

Berdasarkan tabel 3 secara keseluruhan terlihat bahwa kemudahan penggunaan dalam pelayanan tenaga administrasi sekolah urusan kurikulum berbasis teknologi informasi mencapai skor 4,02 dengan kategori baik

4. Rekapitulasi data pelayanan tenaga administrasi sekolah urusan kurikulum berbasis teknologi informasi

Hasil pengolahan data tentang pelayanan tenaga administrasi sekolah urusan kurikulum berbasis teknologi informasi untuk ketersediaan informasi, ketanggapan dan kemudahan penggunaan dapat dilihat pada tabel 4 dengan dengan hasil 3,96 dalam kategori baik

Tabel 4. Rekapitulasi data pelayanan tenaga administrasi sekolah urusan kurikulum berbasis teknologi informasi

\begin{tabular}{|c|l|c|c|}
\hline No. & Indikator & Rata-rata & Kategori \\
\hline 1 & Ketersediaan informasi & 3,83 & Baik \\
\hline 2 & Ketanggapan & 4,04 & Baik \\
\hline 3 & Kemudahan penggunaan & 4,02 & Baik \\
\hline & Rata-rata & 3,96 & Baik \\
\hline
\end{tabular}

Berdasarkan tabel 4 terlihat bahwa tingkat capaian skor tertinggi berada pada indikator ketanggapan dengan skor rata-rata 4,04 dalam kategori baik, sedangkan tingkat capaian skor terendah berada pada indikator ketersediaan informasi dengan skor rata 3,83 dalam kategori baik. Secara keseluruhan pelayanan tenaga administrasi sekolah urusan kurikulum berbasis teknologi informasi mencapai skor 3,96 artinya sudah berjalan dengan baik.

\subsection{Pembahasan}

Pembahasan hasil penelitian mengenai pelayanan tenaga administrasi sekolah urusan kurikulum berbasis teknologi informasi akan diuraikan berdasarkan masing-masing indikator yaitu:

1. Ketersediaan Informasi

Kurangnya keakuratan merupakan skor terendah dalam aspek ketersediaan informasi, kemungkinan penyebab rendahnya skor pada sub indikator tersebut karena kurangnya kecermatan dalam mengukur dan mencatat fakta yang akan mempengaruhi informasi yang dihasilkan. Menurut (Kadir, 2014) akurasi terhadap informasi merupakan faktor yang harus dipenuhi karena ketidakakuratan informasi akan menimbulkan hal yang mengganggu, merugikan, bahkan membahayakan. Mengingat data dari sebuah informasi akan menjadi bahan pengambilan keputusan, sehingga keakuratan informasi harus benar-benar diperhatikan.

\section{Ketanggapan}

Kurangnya kecepatan merupakan skor terendah dalam aspek ketanggapan, kemungkinan rendahnya skor pada sub indikator tersebut karena adanya keterlambatan pemberian informasi dalam pelayanan. Menurut (Kadir, 2003) keterlambatan adalah lamanya waktu berlalu sampai informasi tersebut berada pada tangan penerima. Informasi yang mengalami keterlambatan akan menjadi informasi yang basi 
Ines Chairunnisa ${ }^{1}$, Rusdinal ${ }^{2}$, Ermita $^{3}$, Hanif Al Kadri ${ }^{4}$

Pelayanan Tenaga Administrasi Sekolah Urusan Kurikulum Berbasis Teknologi Informasi di SMK se-Kota

Padang Panjang

dan tidak memiliki nilainya lagi, misalnya untuk pengambilan keputusan. Mengacu pada hal tersebut keterkinian dari sebuah informasi harus sangatlah penting dan informasi harus benar-benar mencerminkan keadaan yang paling baru.

3. Kemudahan Penggunaan

Tidak butuh banyak usaha merupakan skor terendah dalam aspek kemudahan penggunaan. Kemungkinan rendahnya skor pada sub indikator tersebut karena masih banyak pengorbanan yang dilakukan untuk mendapatkan informasi tersebut, seperti memerlukan banyak waktu dan tenaga yang dibutuhkan untuk mendapatkan informasi. Melihat hal tersebut kemudahan dalam mengakses informasi harus ditingkatkan, menurut (Kadir, 2003) kemudahan dalam mengakses informasi harus terjamin agar informasi dapat diterima oleh penerima informasi dengan lancar, maka dari itu suatu informasi tidak hanya sekedar tersedia namun harus mudah untuk dicapai oleh pihak yang membutuhkan informasi.

\section{Kesimpulan}

Berdasarkan hasil penelitian dan pembahasan terkait pelayanan tenaga administrasi sekolah urusan kurikulum berbasis teknologi informasi dapat diambil kesimpulan bahwa dari segi aspek ketersediaan informasi dengan perolehan skor 3,83 sudah berada dalam kategori baik. Dilihat dari aspek ketanggapan dengan perolehan skor 4,04 sudah berada dalam kategori baik dan untuk aspek kemudahan penggunaan dengan ketercapaian skor 4,02 sudah berada dalam kategori baik.

Adapun saran yang dapat diberikan kepada tenaga administrasi sekolah urusan kurikulum adalah agar dapat memiliki kemauan dalam memperbaharui kemampuan dalam menggunakan teknologi informasi serta dalam memberikan pelayanan dapat lebih mengoptimalisasi penggunaan dari teknologi informasi agar informasi yang diberikan dapat diterima oleh pihak yang membutuhkan informasi dengan lebih efektif dan efisien dan kualitas informasi yang diterima akan menjadi lebih baik.

\section{Daftar Rujukan}

Kadir, A. (2003). Pengenalan Sistem Informasi. Yogyakarta: ANDI.

Kadir, A. (2014). Pengenalan Sistem Informasi edisi Revisi. Yogyakarta: ANDI.

Sugiyono. (2018). Metode Penelitian Kuantitatif. Bandung: Alfabeta.

Tjiptono, F. (2012). Service Management: Mewujudkan Layanan Prima. Yogyakarta: ANDI.

Zulkarnain dan Raden. (2015). Manajemen Perkantoran Profesional. Malang: Gunung Samudera. 